\title{
PEMANFAATAN KULIT PISANG (MUSA PARADISIACA) SEBAGAI PEMBUATAN BATERAI PADA PRAKTIKUM ELEKTROKIMIA DI MAN 1 PEKANBARU
}

\author{
Ranti Yanasari ${ }^{1}$, Dra. Fitri Refelita, M.Si ${ }^{2}$. \\ ${ }^{1}$ Prodi Pendidikan Kimia Fakultas Tarbiyah dan Keguruan \\ E-mail rantisari94@yahoo.com \\ ${ }^{2}$ Prodi Pendidikan Kimia Fakultas Tarbiyah dan Keguruan \\ Universitas Islam Negeri Sultan Syarif Kasim Riau \\ E-mail refelitafitri@gmail.com
}

\begin{abstract}
The research on the application of banana skin (Musa Paradisiaca) has been done as a production of natural battery paste. This research is aimed at to see the voltage, light flame, and the endurance that are produced by two varieties of the banana skins. the banana skins that are utilized are the skins of Berangan banana and Kepok banana. Each of the mass samples is 5 grams. In the research, the addition of salt is performed. The KCl salt with different mass is conducted: $0.75 ; 1 ; 1.25 ; 1.5 ; 1.75$ and 2 grams until it reached $1.5-1.8$ volts of voltage. The addition of salt is done to gain a more optimum voltage. The result indicates that the Berangan banana skin has better voltage and endurance comparing to Kepok banana. The voltage that is generated by Berangan banana skin is 1.17 volts with the endurance time of 4 days. After being added with the salt, the voltage increased to 1.54 volts and the endurance of 11 days. For Kepok banana, it is generated 1.00 volts with the endurance time of 3 days. After the salt addition, the voltage increases to 1.52 volts with the endurance of 7 days. The questionnaire of teacher's evaluation about the research result as learning sources at voltage cells practicum gives a cumulative score of $93.75 \%$ which is categorized very good.
\end{abstract}

Keywords: banana skin battery paste, battery, banana skin, voltage, electrolyte.

\section{PENDAHUluAN}

Ilmu kimia merupakan ilmu yang berhubungan dengan kehidupan sehari-hari, diantaranya adalah elektrokimia. Elektrokimia merupakan cabang ilmu yang mempelajari hubungan antara energi listrik dengan reaksi kimia [1]. Sel elektrokimia merupakan sebuah alat khusus yang dapat membuat interaksi antara energi kimia (reaksi kimia) dengan energi listrik. Sel elektrokimia ini terdiri dari dua macam yaitu sel Galvani (sel Volta) dan sel elektrolisis [1].

Sel Galvani (sel Volta) merupakan sebuah sel elektrokimia yang beroperasi secara spontan serta mengubah energi kimia menjadi energi listrik [3]. sel Volta hanya terdiri atas dua elektroda dan elektrolit [3]. Elektrolit pada sistem sel Volta yang sering digunakan pada praktikum disekolah adalah baterai. Baterai merupakan sebuah media yang dapat mengubah energi kimia yang terkandung dalam bahan aktif secara langsung menjadi energi listrik melalui reaksi reduksi dan oksidasi yang terjadi pada elektroda [4].

Baterai merupakan suatu benda yang sudah tidak asing lagi bagi kita. Baterai banyak digunakan dalam kehidupan seharihari, salah satunya pada jam dinding, remot $\mathrm{tv}$, senter dan lain-lain. Baterai terdiri dari tiga komponen penting, yaitu: batang karbon sebagai katoda, seng (Zn) sebagai anoda, dan pasta sebagai elektrolit (pengantar).

Baterai merupakan perangkat yang sering digunakan untuk praktikum kimia disekolah, yaitu pada materi sel volta karena perangkatnya yang sederhana. Materi Sel 
Volta merupakan salah satu materi pelajaran kimia di MAN. Materi ini terkadang susah difahami dan hanya disampaikan sekilas saja oleh guru bahkan tidak disampaikan secara langsung, akibatnya banyak siswa yang kurang paham dengan apa yang disampaikan oleh guru. Bantuan praktikum dalam bentuk yang sederhana dan mudah dimengerti salah satunya seperti produk hasil penelitian sangatlah dibutuhkan. Mendemonstrasikan produk hasil penelitian yang berhubungan dengan materi Sel Volta dapat dijadikan alternatif untuk menyelesaikan beberapa permasalahan tersebut. Produk hasil penelitian bisa digunakan sebagai praktikum yang diharapkan dapat membantu guru dalam menyampaikan materi Sel Volta dengan memberikan contoh yang nyata dalam kehidupan sehari-hari kepada peserta didik.

Namun, baterai ini merupakan bahan yang kurang ramah lingkungan, mengandung logam-logam berat (heavy metal) seperti $\mathrm{MnO}_{2}$, serbuk karbon, $\mathrm{NH}_{4} \mathrm{Cl}$, dan harganya relatif mahal (tidak ekonomis) [4]. Elektrolitelektrolit sintetis tersebut sebenarnya dapat digantikan dengan tumbuhan yang memiliki kandungan senyawa elektrolit yang ramah lingkungan dan tidak mengandung bahan kimia berbahaya serta memiliki harga yang relatif ekonomis Sehingga dapat mengurangi limbah baterai yang ada dilingkungan.

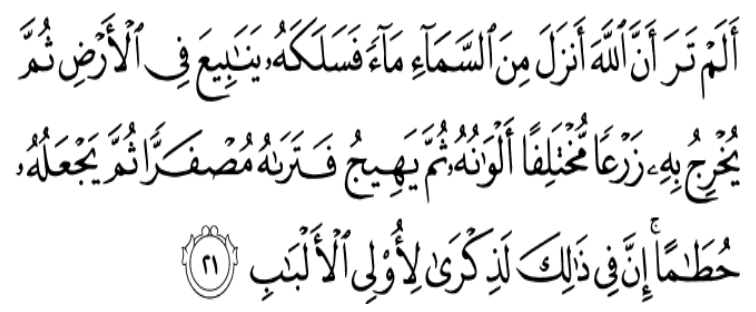

Artinya;

"Apakah engkau tidak memperhatikan, bahwa Allah telah menurunkan air dari langit, lalu diaturnya menjadi sumber-sumber air di bumi, kemudian dengan air itu ditumbuhkanNya tanam-tanaman yang bermacam-macam warnanya, kemudian menjadi kering, lalu engkau melihatnya kekuning-kuningan, kemudian dijadikan-Nya hancur berderaiderai. Sungguh, pada yang demikian itu terdapat pelajaran bagi orang-orang yang mempunyai akal sehat." (QS. Az-zumar: 2)

Dari ayat diatas dapat diambil pelajaran bahawa Allah menciptakan tumbuh-tumbuhan dan buah-buahan yang bermanfaat bagi manusia sebagai tanda kekuasaannya.

Berdasarkan penelitian yang telah dilakukan oleh Fadli, Legowo, dan Purnama, menunjukkan bahwa ragam sayuran maupun buah-buahan telah berhasil didemonstrasikan dan berperan baik sebagai elektrolit pada sistem sel Volta [5]. Berbagai jenis buahbuahan mengandung asam serta mineral yang memiliki banyak manfaat diantaranya sebagai elektrolit, salah satu nya adalah pisang.

Pisang merupakan salah satu jenis tanaman buah tropis yang memiliki banyak manfaat. Salah satunya bermanfaat sebagai sumber makanan, minuman dan pelengkap gizi. Karena pisang kaya akan kandungan gizi yang cukup lengkap seperti karbohidrat, lemak, protein, kalium, fosfor, zat besi, vitamin $\mathrm{B}$, vitamin $\mathrm{C}$ dan air [6]. Indonesia merupakan penghasil pisang terbesar di Asia dan setiap tahun produksinya terus meningkat. Bertambahnya produksi pisang maka semakin banyak pula limbah kulit pisang yang dihasilkan. Pada umumnya limbah kulit pisang hanya dimanfaatkan sebagai pupuk organik atau menjadi pakan ternak saja. Padahal kandungan unsur gizi kulit pisang juga cukup lengkap, seperti karbohidrat, lemak, protein, kalium, fosfor dan air [7].

Dari hasil penelitian sebelumnya tentang pemanfaatan kulit pisang sebagai pengganti baterai yang dilakukan oleh Syifa Fadilah, hasil penelitiannya menyatakan bahwa limbah kulit pisang mengandung mineral yang cukup tinggi sehingga dapat dijadikan sebagai elektrolit pada pembuatan baterai [4]. Pada penelitian ini ingin mencoba kembali melakukan penelitian mengenai pembuatan baterai dari kulit pisang, penelitian ini menggunakan kulit pisang kepok dan barangan. Hal ini ingin melihat perbedaan energi listrik yang dihasilkan, [4].

Berdasarkan hal tersebut maka perlu dilakukan penelitian untuk mengkaji jenis kulit pisang terhadap sifat kelistrikannya, Penelitian ini dapat memberikan gambaran 
terhadap siswa dan masyarakat terutama yang memproduksi pisang dalam skala banyak tentang pemanfaatan limbah kulit pisang yang awalnya dibuang, namun dengan adanya penelitian ini limbah kulit pisang dapat termanfaatkan. Diharapkan dengan penelitian ini juga dapat memberikan informasi ilmiah tentang potensi berbagai jenis kulit pisang sebagai energi alternatif khususnya sebagai energi listrik.

\section{METODE PENELITIAN Waktu dan Tempat Penelitian}

Penelitian dilaksanakan pada bulan maret 2016, Pembuatan pasta kulit pisang sebagai pengganti pasta baterai kering dalam baterai bekas dilaksanakan di Laboratorium Pendidikan Kimia UIN Suska Riau. Sedangkan aplikasi tentang pasta kulit pisang sebagai pengganti pasta baterai pada praktikum sel elektrokimia dilakukan di MAN 1 Pekanbaru.

\section{Subjek dan Objek Penelitian}

Pada penelitian ini yang menjadi subjek penelitian adalah guru MAN 1 Pekanbaru sedangkan objek pada penelitian ini adalah baterai bekas yang telah diisi pasta dari limbah kulit pisang.

\section{Sampel Penelitian}

Sampel pada penelitian ini adalah limbah kulit pisang (Musa Paradisiaca).Kulit pisang yang digunakan adalah kulit pisang berangan dan kepok.

\section{Alat dan Bahan}

Alat

Adapun alat-alat yang digunakan dalam penelitian ini yaitu: baterai bekas ukuran kecil 1,5 volt, kabel, tang, pisau, gunting, mortal, lampu senter, Multitester (voltmeter), kotak karton, timbangan.

\section{Bahan}

Adapun bahan-bahan yang digunakan dalam penelitian ini yaitu Kulit pisang (Musa Paradisiaca), kulit pisang kepok dan kulit pisang barangan, akuades, dan garam $\mathrm{KCl}$.

\section{Prosedur Penelitian \\ Persiapan Baterai}

Disiapkan baterai bekas 1,5 volt, kemudian tutup baterai dan bagian dinding baterai dibuka, dikeluarkan isi baterai dengan hati-hati, setelah itu dibersihkan bagian dalam baterai.

\section{Persiapan Pembuatan Pasta Kulit pisang (Musa Paradisiaca)}

Disiapkan dua jenis kulit pisang, pisang kepok dan barangan. Kemudian dibersihkan, dipotong dan dihaluskan, Setelah dihaluskan ditimbang sebanyak 5 gram. Setelah proses penghalusan selanjutnya dilakukan perlakuan dengan penambahan garam $\mathrm{KCl}$, penambahan garam diberikan secara bervariasai yaitu sebanyak 0,$75 ; 1 ; 1,25 ; 1,5 ; 1,75 ; 2$ gram hingga mendapatkan tegangan 1,5 volt. Setelah kulit pisang berbentuk pasta masukkan kedalam baterai [4].

a. Uji kelistrikan dengan variasi kulit Pisang Kepok dan Pisang Berangan

Pasta kulit pisang kepok dan berangan yang telah ditimbang sebanyak 5 gram dimasukkan kedalam baterai bekas yang sudah dibersihkan. Kemudian dihubungkan dengan volmeter dan dicatat voltase yang dihasilkan. Langkah selanjutnya lepaskan voltmeter dan diganti dengan kabel yang sudah dirangkai dengan lampu senter 1,8-2,1 Volt. Diamati nyala lampu[4].

b. Uji Kelistrikan Variasi Jenis Kulit Pisang Dengan penambahan garam $\mathrm{KCl}(0,75 ; 1$; 1,$25 ; 1,5 ; 1,75 ; 2$ gram) hingga mencapai tegangan 1,5 volt

Pasta kulit pisang kepok dan barangan yang telah ditimbang sebanyak 5 gram dimasukkan kedalam baterai. Ditambakan dengan garam $\mathrm{KCl}$ sebanyak 0,$75 ; 1 ; 1,25$; 1,$5 ; 1,75 ; 2$ gram hingga mencapai tegangan $1,5-1,8$ volt. Kemudian dihubungkan dengan volmeter dan dicatat voltase yang dihasilkan. Langkah selanjutnya lepaskan voltmeter dan diganti dengan kabel yang sudah dirangkai dengan lampu senter 1,8-2,1 Volt. Diamati nyala lampu [4].

c. Uji Daya Tahan Variasi Jenis Kulit Pisang

Uji daya tahan baterai dari kulit pisang diuji dengan menggunakan jam weker, 
uji daya tahan dilakukan dengan variasi jenis kulit pisang untuk mengetahui daya tahan paling optimum yang dihasilkan. uji daya tahan dibanding kan dengan variasi Massa kulit pisang dan penambahan garam $\mathrm{KCl}$ [4].

\section{Teknik Pengumpulan Data}

1. Baterai berpasta kulit pisang

Pengumpulan data awal pada penelitian ini yaitu mengukur nilai tegangan dan nyala lampu baterai yang dihasilkan oleh limbah kulit pisang dengan variasi tanpa penambahan garam dan penambahan garam $\mathrm{KCl}$ sebanyak 0,$75 ; 1 ; 1,25 ; 1,5 ; 1,75$ dan 2 gram hingga mencapai tegangan 1,5 volt.

beberapa guru kimia yang berasal dari sekolah di

Pekanbaru.

\section{Teknik Analisa Data}

1. Pengukuran tegangan dan nyala lampu

Tegangan baterai berpasta kulit pisang diukur menggunakan voltmeter sedangkan kekuatan nyala lampu diamati secara visual.

2. Penilaian angket baterai berpasta kulit pisang

Secara kuantitatif untuk mengakumulasi semua jawaban responden dari setiap soal ditentukan dari persentase hasil penelitian, yaitu dengan menggunakan rumus :

$$
\mathrm{P}=\mathrm{F} / \mathrm{N} \times 100 \%
$$

Tabel 1. Hasil Uji Pengukuran Tegangan Kulit Pisang Kepok Dan Berangan

\begin{tabular}{|c|c|c|c|c|c|c|c|}
\hline \multirow{2}{*}{ Sampel } & \multicolumn{4}{|c|}{ Voltase yang dihasilakan } & \multicolumn{3}{|c|}{$\begin{array}{c}\text { Nyala Lampu Yang di } \\
\text { Hasilkan }\end{array}$} \\
\hline & I & II & III & $\begin{array}{c}\text { Rata- } \\
\text { rata }\end{array}$ & Terang & Redup & $\begin{array}{l}\text { Tidak } \\
\text { Nyala }\end{array}$ \\
\hline $\begin{array}{l}\text { Baterai pasta kulit } \\
\text { pisang kepok }\end{array}$ & $\begin{array}{l}0,8 \\
\text { volt }\end{array}$ & $\begin{array}{l}1,10 \\
\text { volt }\end{array}$ & $\begin{array}{l}1,10 \\
\text { volt }\end{array}$ & $\begin{array}{l}1,00 \\
\text { volt }\end{array}$ & & t+ & \\
\hline $\begin{array}{l}\text { Baterai pasta kulit } \\
\text { pisang berangan }\end{array}$ & $\begin{array}{l}1,20 \\
\text { volt }\end{array}$ & $\begin{array}{l}1,10 \\
\text { volt }\end{array}$ & $\begin{array}{l}1,20 \\
\text { volt }\end{array}$ & $\begin{array}{l}1,17 \\
\text { volt }\end{array}$ & & + & \\
\hline
\end{tabular}

Tabel 2. Hasil Uji Pengukuran Tegangan Kulit Pisang Kepok Dan Berangan Dengan Penambahan Variasi Garam

\begin{tabular}{|c|c|c|c|c|}
\hline so & Jenis kulit pisang & $\begin{array}{c}\text { Variasi massa } \\
\text { garam }\end{array}$ & $\begin{array}{c}\text { Voltase yang } \\
\text { dihasilkan }\end{array}$ & $\begin{array}{l}\text { Nyala } \\
\text { lampu }\end{array}$ \\
\hline & & 0,75 gram & $1,20 \mathrm{v}$ & Redup \\
\hline \multirow[t]{7}{*}{1.} & Pisang berangan & 1 gram & $1,25 \mathrm{v}$ & Redup \\
\hline & & 1,25 gram & $1,38 \mathrm{v}$ & Redup \\
\hline & & 1,5 gram & $1,45 \mathrm{v}$ & Terang \\
\hline & & 1,75 gram & $1,50 \mathrm{v}$ & Terang \\
\hline & & 2 gram & $1,54 \mathrm{v}$ & Terang \\
\hline & & 0,75 gram & $1,13 \mathrm{v}$ & Redup \\
\hline & & 1 gram & $1,20 \mathrm{v}$ & Redup \\
\hline \multirow[t]{4}{*}{2.} & Pisang kepok & 1,25 gram & $1,26 \mathrm{v}$ & Redup \\
\hline & & $1,5 \mathrm{gram}$ & $1,35 \mathrm{v}$ & Redup \\
\hline & & 1,75 gram & $1,46 \mathrm{v}$ & Terang \\
\hline & & 2 gram & $1,52 \mathrm{v}$ & Terang \\
\hline
\end{tabular}

2. Angket kelayakan baterai berpasta kulit pisang

Pengumpulan data selanjutnya yaitu berupa angket. Angket tersebut akan diisi oleh beberapa orang guru mata pelajaran kimia yang diambil dari sekolah yang ada di kota Pekanbaru, untuk mengetahui kelayakan limbah kulit pisang sebagai pengganti pasta baterai kering dalam baterai bekas dan aplikasinya pada praktikum sel elektrokimia di Sekolah Menengah Atas. Angket yang diujikan oleh peneliti berjumlah enam pertanyaan yang telah dilakukan validitas oleh validator. Apabila layak menurut responden, maka kulit pisang dapat dijadikan sebagai pengganti pasta baterai dan diaplikasikan pada praktikum sel elektrokimia di Sekolah.

\section{HASIL DAN PEMBAHASAN}

\section{Hasil}

1. Hasil Tegangan dan Nyala Lampu Baterai Berpasta Kulit Pisang

Tegangan baterai berpasta kulit pisang ini diukur menggunakan voltmeter dan nyala lampu diuji menggunakan lampu senter 2,5 volt.

Tabel 3. Hasil Uji Pengukuran Daya Ketahanan Kulit Pisang Kepok Dan Berangan Yang Diuji Dengan Jam weker

\begin{tabular}{ccccc}
\hline NO & Pisang kepok & Daya Tahan & Pisang Berangan & Daya Tahan \\
\hline 1. & $1,00 \mathrm{~V}$ & 3 hari & $1,17 \mathrm{~V}$ & 4 hari \\
2. & $1,13 \mathrm{~V}$ & 4 hari & $1,20 \mathrm{~V}$ & 6 hari \\
3. & $1,20 \mathrm{~V}$ & 4 hari & $1,25 \mathrm{~V}$ & 7 hari \\
4. & $1,26 \mathrm{~V}$ & 5 hari & $1,38 \mathrm{~V}$ & 8 hari \\
5. & $1,35 \mathrm{~V}$ & 5 hari & $1,45 \mathrm{~V}$ & 9 hari \\
6 & $1,46 \mathrm{~V}$ & 6 hari & $1,50 \mathrm{~V}$ & 9 hari \\
7. & $1,52 \mathrm{~V}$ & 7 hari & $1,54 \mathrm{~V}$ & 11 hari \\
\hline
\end{tabular}

Tabel 4. Hasil Jawaban Penilaian Guru Responden Terhadap Baterai Berpasta Kulit pisang

\begin{tabular}{lccccc}
\hline \multirow{2}{*}{ N0 } & \multirow{2}{*}{ Indikator } & \multicolumn{4}{c}{ Persentase \% } \\
\cline { 3 - 6 } & & SB & B & CB & KB \\
\hline 1 & Voltase Yang dihasillkan & 0 & 100 & 0 & 0 \\
2 & Kepraktisan & 100 & 0 & 0 & 0 \\
3 & Keekonomisan & 50 & 50 & 0 & 0 \\
4 & Kelayakan & 100 & 0 & 0 & 0 \\
5 & Naten & 100 & 0 & 0 & 0 \\
5 & 100 & 0 & 0 & 0 \\
\hline
\end{tabular}




\section{Pembahasan}

1. Baterai berpasta kulit pisang

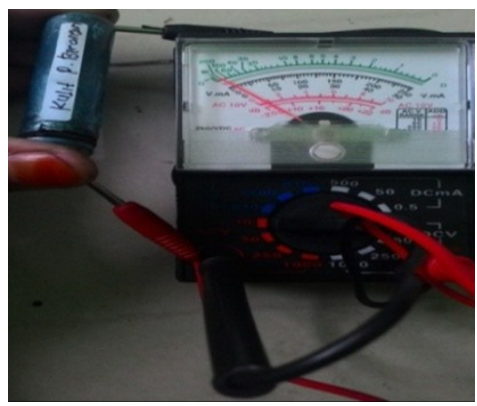

(a)

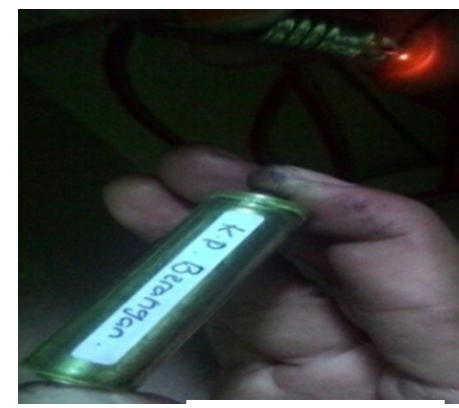

(b)

Gambar 1. a). Hasil tegangan baterai dari pasta kulit pisang berangan, b). Uji nyala lampu baterai kulit pisang berangan.

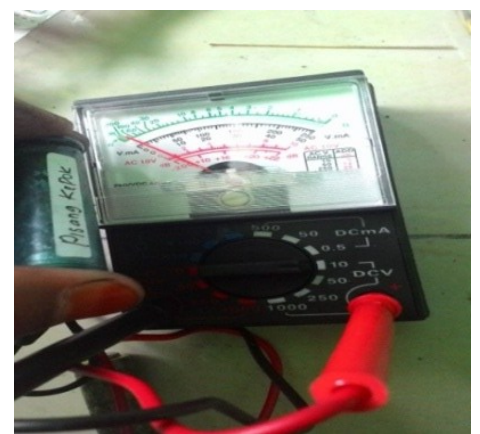

(a)

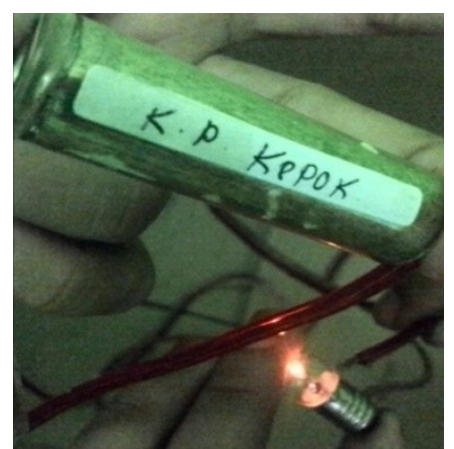

(b)

Gambar 2. a). Hasil tegangan baterai dari pasta kulit pisang kepok, b). Uji nyala lampu baterai kulit pisang kepok

Pada penelitian ini kulit pisang dijadikan sebagai pasta baterai yaitu dengan membuat batu baterai yang ramah lingkungan dari limbah kulit pisang. Dengan cara menggantikan Mangan Oksida atau elektrolit pada baterai yang sudah tidak bisa digunakan, diganti dengan elektrolit dari kulit pisang sehingga kita bisa menggunakan baterai itu kembali. Disini menggunakan dua jenis kulit pisang yaitu pisang kepok dan pisang berangan, dan akan melihat perbedaan voltase dan nyala lampu yang dihasilkan.

Pada penelitian ini dilakukan kajian pembuatan baterai dengan limbah kulit pisang, dengan melihat perbedaan tegangan yang dihasilkan antara pisang kepok dengan pisang berangan. Dari tabel diatas terlihat bahwa tegangan yang dihasilkan kulit pisang kepok dan pisang berangan lebih besar tegangan yang dihasilkan oleh pisang berangan yaitu $1,17 \mathrm{v} / \mathrm{m}$ dan nyala lampu yang dihasilkan redup dan kulit pisang kepok sebesar $1,00 \mathrm{v} / \mathrm{m}$ dengan nyala lampu redup.

Pada cara kerja baterai yang bertindak sebagai anoda adalah batang karbon dan katoda adalah seng dengan elektrolit yang digunakan yaitu dari pasta kulit pisang. Pada anoda terjadi oksidasi dan elektron bergerak menuju elektrode. Jika elektrode ini dihubungkan dengan lampu maka lampu akan 
menyala, hal ini membuktikan adanya arus listrik, ketika lampu menyala larutan elektrolit bereaksi dengan seng.

Disini terlihat kulit pisang barangan lebih besar tegangan nya, hal ini disebabkan karena kandungan mineral kulit pisang barangan lebih tinggi. Walaupun tidak ditemui secara spesifik mengenai kandungan yang ada pada pisang barangan tetapi berdasarkan teori perbedaan nilai kelistrikan pada setiap jenis kulit pisang dipengarui oleh banyaknya kandungan mineral yang terdapat pada setiap jenis kulit pisang [8]. Diketahui bahwa kulit pisang kaya akan mineral seperti kalium, megnesium, fosfor, klorida, kalsium, dan besi.

Berdasarkan jurnal Yasni Nopi Hendri dan Muh Muhlisin, dijelaskan bahwa yang menjadi parameter kelistrikan suatu bahan yaitu banyaknya kandungan air, fosfor, clorida dan kalium. Kalium $\left(\mathrm{k}^{+}\right)$berperan dalam proses listrik. Kalium akan bereaksi dengan garam klorida membentuk garam kalium klorida. Garam kalium klorida dalam air yang mengandung ion dapat mengantarkan arus listrik karena dapat terionisasi. Arus listrik dapat mengalir karena seng bertindak sebagai katode (kutub +) yang bersifat menarik ion negatif dan tembaga bertindak sebagai anode (kutub -) yang bertindak menarik ion positif. Ketika pasta kulit pisang bersentuhan dengan unsur seng dan tembaga maka akan terjadi reaksi ionisasi sehingga akan terjadi aliran elektron yang menyebabkan arus listrik mengalir. Jika kedua elektrode dihubungkan dengan lampu arus akan mengalir dari anode ke katode, dan lampu akan menyala [8].

Air yang terkandung dalam kulit pisang mengandung partikel bermuatan yang meliputi ion positif dan negatif yang dapat berperan dalam proses transfer elektron. Banyaknya jumla ion-ion nantinya akan berperan dalam mengantarkan arus listrik. Apabila suatu bahan yang terdapat ion-ion didalamnya diberikan dua buah elektroda yang memiliki beda potensial maka ion-ion didalamnya akan terdisosiasi dan mengalami proses elektrolitik.

Proses elektrolitik ini dapat mengakibatkan adanya pertukaran ion yang nantinya akan menyebabkan sebuah aliran elektron dari beda potensial yang menghasilkan tegangan dan arus listrik.

Dari penjelasan diatas terlihat bahwa pisang berangan memiliki tegangan yang lebih besar salah satu faktor nya adalah kandungan air yang mengandung ion-ion. Hal ini sesuai dengan teori yang didapatkan bahwa kemampuan larutan untuk mengantarkan arus listrik bergantung pada jumlah ion yang dikandungnya [8]. Pada penilitian ini menggunakan kulit pisang yang masak disini dianalogikan pada hambatan. Dimana jika menggunakan kulit pisang yang muda maka besar hambatan pergerakan elektron sehingga arus bernilai kecil. Jika menggunakan kulit pisang yang masak hambatan bernilai kecil sehingga nilai kuat arus menjadi besar dan pergerakan elektron menjadi mudah.

Kulit pisang juga mengandung karbohidrat, karbohidrat mengandung glukosa, yang apabila bercampur dengan air dan didiamkan selama beberapa hari akan terjadi proses fermentasi sehingga akan terbentuk etanol. Etanol lama kelamaan akan teroksidasi menjadi asam asetat. Asam asetat merupakan jenis zat elektrolit, sehingga bisa menghasilkan arus listrik [7]. Reaksi yang terjadi:

\section{$\mathrm{C} 6 \mathrm{H} 12 \mathrm{O} \longrightarrow \mathrm{CH} 3 \mathrm{CH} 2 \mathrm{H}+[\mathrm{O}] \longrightarrow \mathrm{CH} 3 \mathrm{COOH}$}

Glukosa Etanol Asam Asetat

ada beberapa hal yang menyebab kan nilai tegangan pada baterai tidak konstan, diantaranya adalah massa elektrolit yang dimasukkan kedalam baterai, dimana massa yang lebih banyak menghasilkan nilai tegangan yang lebih besar dibandingkan massa yang sedikit. Pembungkus kulit yang sudah terbuka juga berpengaruh terhadap nilai tegangan.

Pada penelitian ini memilih menggunakan garam $\mathrm{KCl}$ karena garam $\mathrm{KCl}$ merupakan garam yang termasuk elektrolit kuat. Menurut penelitian yang dilakukan Syifa, $\mathrm{KCl}$ menghasilkan tegangan yang baik diantara yang lain, karena $\mathrm{KCl}$ dapat terionisasi secara sempurna menjadi $\mathrm{K}^{+}+\mathrm{Cl}^{-}$sehingga $\mathrm{KCl}$ 
lebih mudah menghantarkan listrik. Selain itu pada kulit pisang mengandung kalium dan garam klorida yang ketika bereaksi akan membentuk garam kalium klorida. Sehingga garam $\mathrm{KCl}$ lah yang tepat untuk ditambahkan pada pasta kulit pisang [7].

$$
\mathrm{KCl} \longrightarrow \mathrm{K}^{+}+\mathrm{Cl}^{-}
$$

Berikut adalah grafik hubungan antara variasi jumlah garam dengan voltase yang dihasilkan sel Volta kulit pisang barangan dan dan pisang kepok.

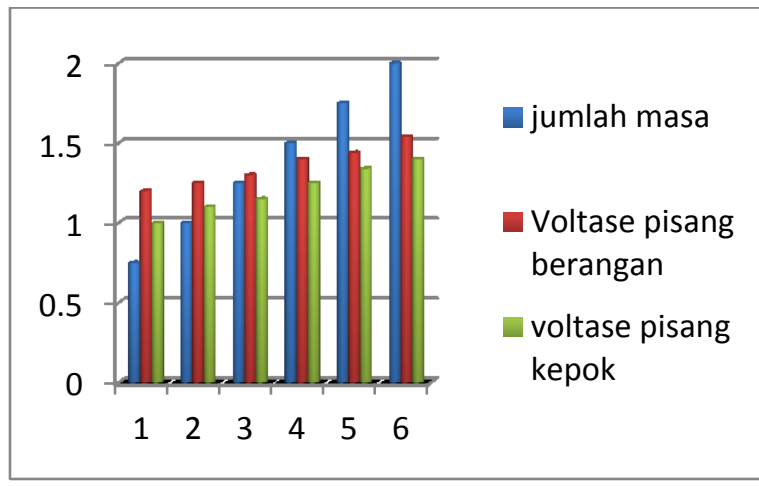

Sumbu X menyatakan variasi perlakuan Sumbu Y menyatakan voltase dan massa garam

Dari grafik terlihat bahwa semakin banyak garam yang ditambahkan maka semakin besar voltase yang dihasilkan. Pada pisang berangan untuk menghasilkan voltase $1,5 \mathrm{v}$ membutuhkan 1,75 gram garam dan pada pisang kepok untuk menghasilkan voltase 1,5 $\mathrm{v}$ membutuhkan garam yang lebih banyak yaitu 2 gram garam. Hal ini disebabkan karena pengaruh kandungan yang ada pada masing-masing kulit pisang, diatas dijelaskan bahwa kandungan kelistrikan kulit pisang berangan lebih besar dibandingkan kulit pisang kepok, jadi ketika ditambah kan garam untuk menghasilkan tegangan yang optimum pisang berangan hanya membutuhkan sedikit garam dibanding dengan pisang kepok.

\section{SIMPULAN}

Berdasarkan hasil penelitian dan pembahasan dalam penelitian ini dapat diambil kesimpulan yaitu kulit pisang barangan dan kulit pisang kepok berpotensi sebagai pengganti pasta baterai dan dapat dilihat bahwa kulit pisang barangan menghasilkan arus listrik yaitu 1,17 volt, sedangkan untuk kulit pisang kepok menghasilkan 1,00 volt, dengan nyala lampu yang dihasilkan yaitu redup. Pada pisang barangan massa $\mathrm{KCl}$ yang dibutuhkan untuk mencapai 1,5 volt adalah 1,75 gram. Sedangkan untuk pisang kepok membutuhkan 2 gram garam. Hasil angket penilaian guru terhadap kelayakan sebagai praktikum dari penelitian pemanfaatan kulit pisang sebagai pembuatan baterai pengganti larutan elektrolit sel volta pada praktikum sel elektrokimia diperoleh nilai kumulatif sebesar 93,75\%. Termasuk pada kategori sangat baik dengan rentang $81 \%-100 \%$.

\section{REFERENSI}

[1] S. Syukri, "Kimia dasar 3,"Bandung: ITB, 1994, 513-514.

[2] Oxtoby, W David, "Prinsip-prinsip Kimia Modern,"Jakarta: Erlangga, 2001, 379.

[3] Ahmad, Hiskia, "Elektrokimia dan Kinetika Kimia," Bandung: PT Citra Aditya Bakti, 2001, 206.

[4] S. Fadilah, Pembuatan Biomaterial dari Limbah Kulit Pisang, Journal Prosiding Simposium Nasional Inovasi dan Pembelajaran Sains, Bandung, Indonesia, 2015, 45.

[5] Mahfudli Fadli, Ulfa, Demonstrasi Sel Volta Buah Nanas (Ananas Comosus L.Mer, Jurusan Fisika FMIPA, Journal Universitas Sebelas Maret Indonesia, 2012, 176.

[6] Purwanto, Agus, (Produksi Nata Menggunakan Limbah Beberapa Jenis Kulit Pisang, Journal Program Studi Biologi Fakultas MIPA UKWMM), 2012, 212.

[7] M. Mukhlisin, "Pemanfaatan Sampah Kulit Pisang dan Kulit Durian sebagai Bahan Alternatif Pengganti Pasta Batu 
Baterai", Journal Teknik Elektro, Lampung, 2015. 147.

[8] Novi hendri, Yasni, "Pengaruh jenis kulit pisang dan variasi waktu fermentasi terhadap kelistrikan dari sel ACCU Dengan menggunakan larutan kulit pisang". Journal Jurusan Fisika FMIPA UNP, Padang, 2015. 